Kajian Jurnalisme

ISSN 2549-0559 (cetak) ISSN 2549-1946 (online)

Volume 02 Nomor 01 Tahun 2018

\title{
Konstruksi Realitas Wartawan Kantor Berita Radio Atas Kesejahteraan Jurnalis
}

\author{
Luqman Alfarisi dan Gumgum Gumilar \\ Fakultas Ilmu Komunikasi, Universitas Padjadjaran \\ luqmanalf@gmail.com
}

\begin{abstract}
This research is about a study of Kantor Berita Radio journalist's reality construction of journalist welfare. As the analysis, researchers used two main theories, namely the theory of social reality construction by Peter Berger and Thomas Luckmann, and the social phenomenology theory by Alfred Schutz. This study aims to find out and understand the explanation of the meaning of journalist welfare, knowing this research subject motives' in being a journalist, and seeing the implifications of the meaning of welfare on the quality and quantity of journalistic works produced. As a result, in general, each informant has a different process of meaning their welfare. The results of the study prove that welfare isn't only measured in terms of materialistic things. There are three aspects used, including: material welfare; social welfare; and mental or psychological welfare. In addition, each informant has their own motives in choosing a profession as a journalist that can be examined with social phenomenology theory, which is divided into pastness (because-motive) and futureness (in-order-tomotive) that are strongly influenced by experience and knowledge of each informant. All informant considered that the welfare they felt had implications on their journalistic works, especially in terms of the quality and quantity.
\end{abstract}

Keywords: Phenomenology, Social Construct, Welfare, Journalist

\begin{abstract}
Abstrak
Penelitian ini membahas konstruksi realitas wartawan Kantor Berita Radio atas kesejahteraan jurnalis. Sebagai pisau analisis, peneliti menggunakan dua teori utama, yaitu teori konstuksi realitas sosial dari Peter Berger dan Thomas Luckmann, serta teori fenomenologi sosial dari Alfred Schutz. Penelitian ini bertujuan untuk mengetahui dan memahami pemaparan atas makna kesejahteraan wartawan; motif dari subjek penelitian dalam menjadi wartawan, serta melihat implikasi pemaknaan kesejahteraan oleh watawan Kantor Berita Radio terhadap kualitas dan kuantitas karya jurnalistik yang diproduksi. Hasilnya, secara umum, setiap informan memiliki proses pemaknaan atas kesejahteraan yang berbeda-beda. Ada tiga aspek yang digunakan, di antaranya: material; sosial; serta mental atau psikologis. Selain itu, setiap informan memiliki motif-motif tersendiri dalam memilih profesi sebagai jurnalis yang dapat ditelisik dengan teori fenomenologi sosial yang terbagi dalam motif masa lalu (because-motive) dan motif masa depan (in-order-to-motive). Semua informan menilai bahwa kesejahteraan yang mereka rasakan memiliki implikasi terhadap karya jurnalistik mereka, terutama dalam hal kualitas dan kuantitas.
\end{abstract}

Kata kunci: Fenomenologi, Kesejahteraan, Konstruksi Sosial, Wartawan 
45 | Kajian Jurnalisme

ISSN 2549-0559 (cetak) ISSN 2549-1946 (online)

Volume 02 Nomor 01 Tahun 2018

\section{Pendahuluan}

Kesejahteraan kerap menjadi pembahasan hangat pada sejumlah lapisan masyarakat, terutama dalam dunia kerja/profesional. Isu kesejahteraan ini yang menjadi pembahasan utama dalam penelitian ini, di mana wartawan Kantor Berita Radio (KBR) yang memaknai kesejahteraan itu sendiri selama menjalani profesinya di media bersangkutan.

Pengalaman menjalani Praktik Kerja Lapangan (PKL) di Kantor Berita Radio pada bulan Juli hingga Agustus 2016 lalu menunjukkan fakta-fakta yang baru ditemukan selama di lapangan, tentunya pengalaman selaku wartawan. Kegiatan wartawan mulai dari mengumpulkan informasi, proses peliputan, hingga proses produksi berita, turut dialami semua selama tepat 45 hari kerja efektif di Kantor Berita Radio. Namun, selain pengalaman menjalani profesi sebagai wartawan, adapun sejumlah problema yang dihadapi wartawan-wartawan di media bersangkutan, dalam hal ini masalah tentang kesejahteraan.

Sejumlah keluhan tersebut umumnya datang dari para wartawan yang sudah bekerja di KBR lima tahun ke atas. Berdasarkan hasil wawancara dengan ketua Serikat Pekerja KBR, Sasmito, penyebabnya meliputi soal kenaikan gaji, dan fasilitas. Hal ini menjadi masalah karena secara tidak langsung loyalitas wartawan terhadap perusahaan kurang dihargai. Ditambah juga dengan wartawan yang telah menjajaki profesinya cukup lama di KBR rata-rata sudah berkeluarga dan memiliki kebutuhan lebih. Dengan kondisi gaji tersebut, tak jarang keluhan datang dari para wartawan tersebut.

Sejahtera (KBBI) artinya aman sentosa, makmur, dan terlepas dari gangguan. Sedangkan kesejahteraan diartikan sebagai keadaan sejahtera, keamanan, dan ketentraman. Pasal 1 ayat 1 Undang-Undang No. 11 Tahun 2009 tentang kesejahteraan sosial, menjelaskan kesejahteraan sosial sebagai kondisi terpenuhinya kebutuhan material, spiritual, dan sosial warga negara agar dapat hidup layak dan mampu mengembangkan diri, sehingga dapat melaksanakan fungsi sosialnya. Standar kebutuhan hidup layak (KHL) berdasarkan keputusan Menteri Tenaga Kerja No. 13 Tahun 2012, terdiri atas biaya untuk makanan dan minuman, sandang, perumahan, pendidikan, kesehatan, transportasi, serta rekreasi dan tabungan.

Menurut Kolle dalam Bintarto (1989), memberikan beberapa aspek pengukur kesejahteraan, yaitu: Pertama, kualitas hidup materi seperti bahan pangan, rumah, dan sebagainya. Kedua, kualitas hidup fisik, seperti lingkungan, kesehatan, dan sebagainya. Ketiga, kualitas hidup mental, seperti fasilitas pendidikan, lingkungan budaya, dan sebagainya. Keempat, kualitas hidup spiritual seperti moral, etika, keserasian penyesuaian, dan sebagainya.

Kantor Berita Radio (KBR) sendiri merupakan media massa radio (berita) swasta dengan jaringan terbanyak di Nusantara-atas penghargaan dari Museum Rekor-Dunia Indonesia pada tahun 2006 - ada sekitar 900 radio jaringan berdasarkan data profil perusahaan KBR. Media massa yang berbasis di Ibu Kota Jakarta ini juga menyajikan siaran beritanya hingga kawasan Asia dan Australia dengan program Asia Calling. Tercatat, ada sekitar 321 jaringan di kawasan Asia yang menyiarkan program ini, dengan total sekitar 10 bahasa terjemahan. Didirikan pada akhir masa Orde Baru tahun 1998 oleh para aktivis dari Komunitas 
Utan Kayu, KBR hingga kini tetap dikenal sebagai lembaga kantor penyedia berita radio independen pertama di Indonesia. Hal ini berbanding lurus dengan berbagai penghargaan dan juga prestasi yang telah digapai KBR serta para jurnalisnya.

Hal ini bertolak belakang dengan keadaan/status dari Kantor Berita Radio sendiri yang sebelumnya sudah dijabarkan di atas. Status KBR selaku media massa radio swasta dengan jaringan terbanyak di Indonesia dapat dijadikan perbandingan dengan media massa radio swasta berbasis di Jakarta lainnya yang memiliki jaringan relatif lebih sedikit, seperti stasiun radio Elshinta yang hanya memiliki 38 jaringan di Nusantara, Sindo Trijaya sekitar 40 jaringan di Nusantara, serta sejumlah stasiun radio lain.

Penelitian ini akan menggali motif informan menjadi wartawan di Kantor Berita Radio, pemaknaan informan mengenai kesejahteraan, serta implikasi pemaknaan kesejahteraan oleh informan terhadap karya jurnalistik yang dihasilkan. Hal ini menjadi penting untuk memberikan gambaran realitas wartawan kepada calon jurnalis sebagai pertimbangan pemilihan karir. Selain itu, memberikan pemahaman bahwa pemaknaan terhadap kesejahteraan dapat memengaruhi motif berkarya informan dalam bentuk pemberitaan yang sangat dibutuhkan masyarakat.

Penelitian ini pun akan mengambil wartawan Kantor Berita Radio sebagai subjek dengan rincian editor, koordinator liputan (korlip), dan reporter. Selain itu, mengingat pengalaman Praktik Kerja Lapangan di media terkait, kondisi lapangan serta kegiatan seharihari yang dilakukan telah didapatkan secara cukup gamblang dan dapat membantu memberikan gambaran terhadap penelitian ini. Bentuk-bentuk pengalaman selama mereka menjadi wartawan langsung dilihat dari sudut pandang orang yang mengalaminya. Untuk itu, dilakukan klasifikasi tak hanya pada setiap tindakan sadar, tetapi juga pada tindakan di masa datang.

Dari pemaparan latar belakang tersebut, rumusan masalah penelitian ini adalah “Bagaimana konstruksi realitas wartawan Kantor Berita Radio atas kesejahteraan jurnalis?". Dengan tujuan mengetahui pemaparan atas makna kesejahteraan wartawan oleh wartawan, mengetahui motif dari subjek penelitian dalam menjadi wartawan, serta mengetahui implikasi pemaknaan kesejahteraan oleh wartawan Kantor Berita Radio terhadap kualitas karya jurnalistik yang diproduksi.

\section{Metode}

Alfred Schutz dalam Kuswarno (2009:2) menyatakan bahwa fenomenologi mencoba mencari pemahaman bagaimana manusia mengkonstruksi makna dan konsep-konsep penting dalam kerangka intersubjektivitas. Intersubjektif karena pemahaman kita mengenai dunia dibentuk oleh hubungan kita dengan orang lain. Maka dari itu, penelitian ini menggunakan metodologi penelitian kualitatif studi fenomenologi Alfred Schutz, dengan tujuan untuk menggali pemahaman dan konstruksi makna dari wartawan Kantor Berita Radio berdasarkan pengalamannya selama bekerja di media bersangkutan.

Dalam penelitian ini teknik pengumpulan data yang utama yaitu wawancara, baik terekam maupun tidak terekam; dan observasi partisipan. Data pendukung lainnya diperoleh 
47 | Kajian Jurnalisme

ISSN 2549-0559 (cetak) ISSN 2549-1946 (online)

Volume 02 Nomor 01 Tahun 2018

melalui dokumen-dokumen lainnya.

Uji kredibilitas data atau kepercayaan terhadap data hasil penelitian kualitatif antara lain dilakukan dengan perpanangan pengamatan, peningkatan ketekunan dalam penelitian, triangulasi, diskusi dengan teman sejawat, analisis kasus negatif, dan member check. Kemudian pengujian transferability yang menunjukkan derajat ketepatan atau dapat diterapkannya hasil penelitian ke populasi di mana sampel tersebut diambil. Nilai transfer ini berkenaan dengan pertanyaan, hingga mana hasil penelitian dapat diterapkan atau digunakan dalam situasi lain. Selanjutnya pengujian dependability disebut reliabilitas, yakni apabila orang lain dapat mengulangi/mereplikasi proses penelitian tersebut. Uji dependability dilakukan denan melakukan audit terhadap keseluruhan proses penelitian. Lalu, pengujian confirmability berarti menguji hasil penelitian, dikaitkan dengan proses yang dilakukan.

Dalam penelitian ini, peneliti menggunakan teknik sampel purposif, atau teknik pengambilan sampel bertujuan. Kriteria yang akan digunakan yakni sebanyak empat orang informan yang mampu mewakili realitas yang diteliti. Objek penelitian adalah pemaknaan atas kesejahteraan. Objek tersebut akan digali dari wartawan pada sebuah perusahaan media massa bernama Kantor Berita Radio.

\section{Kajian Pustaka}

Penggunaan teori fenomenologi Alfred Schutz dalam penelitian ini memiliki tugas utama untuk merekonstruksi dunia kehidupan manusia (wartawan) sebenarnya dalam bentuk yang mereka sendiri alami. Realitas dunia tersebut bersifat intersubjektif dalam arti bahwa anggota masyarakat berbagi persepsi dasar mengenai dunia yang mereka internalisasikan melalui sosialisasi dan memungkinkan mereka melakukan interaksi atau komunikasi.

Dalam konteks fenomenologis, wartawan KBR adalah "aktor” (istilah menurut Schutz) yang melakukan tindakan sosial bersama aktor lainnya sehingga memiliki kesamaan dan kebersamaan dalam ikatan makna intersubjektif. Para wartawan juga memiliki historisitas dan dapat dilihat dalam bentuk yang alami. Wartawan KBR sebagai aktor memiliki dua motifyang berorientasi ke masa depan (in order to motive) dan motif berorientasi ke masa lalu (because motive). Motif tersebut akan menentukan penilaian terhadap diri subjek sendiri dalam statusnya sebagai wartawan.

Schutz dalam Kuswarno (2009:110) juga menyampaikan bahwa konsep sosial didefinisikan sebagai hubungan antara dua atau lebih orang, dan konsep tindakan didefinisikan sebagai perilaku yang membentuk makna subjektif. Schutz juga menyimpulkan bahwa tindakan sosial adalah tindakan yang berorientasi pada perilaku seseorang atau orang lain pada masa lalu, sekarang, dan yang akan datang.

Pemaknaan atas kesejahteraan berangkat dari wartawan KBR yang menghadapi kenyataan/realitas pada kesehariannnya. Menurut Peter L. Berger dan Thomas Luckmann (2013:1) dalam bukunya Tafsir Sosial atas Kenyataan sebagai suatu kualitas yang terdapat dalam fenomena-fenomena yang kita akui sebagai memiliki keberadaan (being) yang tidak tergantung kepada kehendak kita sendiri, sedangkan pengetahuan didefinisikan sebagai 
kepastian bahwa fenomena-fenomena itu nyata (real) dan memiliki karakteristik-karakteristik yang spesifik.

Teori konstruksi realitas sosial Peter L. Berger \& Thomas Luckmann sendiri memiliki asumsi dasar intersubjektivitas dalam konstruksi realitas sosial yang melalui tiga momen dialektis, yakni eksternalisasi (society is a human product), objektivasi (society is an objective reality), dan internalisasi (man is a social product). Berdasarkan asumsi dasar tersebut akan terlihat bagaimana makna atau realitas sosial tersebut dikonstruksikan. "Oleh karena itu masyarakat berada baik sebagai kenyataan obyektif maupun subyektif, maka setiap pemahaman teoretis yang memadai mengenai masyarakat harus mencakup kedua aspek itu. Seperti telah kami kemukakan, aspek-aspek itu memperoleh pengakuan yang semestinya apabila masyarakat dipahami dari segi suatu proses dialektis yang berlangsung terus-menerus dan terdiri dari tiga momen: eksternalisasi, obyektivasi dan internalisasi. Sejauh yang menyangkut fenomena masyarakat, momen-momen itu tidak dapat dipikirkan sebagai berlangsung dalam suatu urutan waktu. Yang benar adalah bahwa masyarakat dan tiap bagian darinya secara serentak dikarakterisasi oleh ketiga momen itu. Sehingga setiap analisa yang hanya dari satu atau dua segi dari ketiga momen itu, tidak memadai. Hal itu juga berlaku bagi anggota masyarakat secara individual, yang secara serentak mengeksternalisasi keberadaannya sendiri ke dalam dunia sosial dan menginternalisasinya sebagai suatu kenyataan obyektif. Dengan kata lain, berada dalam masyarakat berarti berpartisipasi dalam dialektika itu," (Berger \& Luckmann, 2013: 176).

Kaitannya dengan konsep realitas sosial tersebut, wartawan memiliki realitas objektif dan subjektif melalui proses simultan eksternalisasi, objektifikasi, dan internalisasi. Dalam proses eksternalisasi, wartawan Kantor Berita Radio menyesuaikan diri dengan dunia sosiokultural. Kemudian, wartawan terpengaruh melalui interaksi sosial dalam dunia intersubjektif atau disebut proses objektifikasi. Proses eksternalisasi dan objektifikasi ini yang membuat wartawan tersebut melakukan proses internalisasi, yaitu mengidentifikasi dirinya dengan lingkungannya.

\section{Hasil dan Pembahasan}

Dalam memaknai kesejahteraannya, informan bebas mengonstruksi dunia sosial sesuai kehendaknya. Ia bahkan dapat memaknai suatu hal secara berbeda dari yang dipahami masyarakat pada umumnya. Pemaknaan seorang wartawan mengenai kesejahteraannya sangat dipengaruhi oleh pengetahuannya. Dalam mengonstruksikan realitas atas kesejahteraan, para informan akan melewati proses intersubjektivitas. Pemaknaan informan mengenai kesejahteraannya akan dipengaruhi oleh hubungan dengan orang lain, baik dalam interaksi personal maupun dalam interaksi yang lebih luas seperti pada masyarakat.

\section{Konstruksi Sosial Mengenai Kesejahteraan}

Teori konstruksi realitas sosial Peter L. Berger \& Thomas Luckmann memiliki asumsi dasar intersubjektivitas dalam konstruksi realitas sosial yang melalui tiga momen dialektis, 
49 | Kajian Jurnalisme

ISSN 2549-0559 (cetak) ISSN 2549-1946 (online)

Volume 02 Nomor 01 Tahun 2018

yakni eksternalisasi (society is a human product), objektivasi (society is an objective reality), dan internalisasi (man is a social product). Berdasarkan asumsi dasar tersebut akan terlihat bagaimana makna atau realitas sosial tersebut dikonstruksikan.

Kaitannya dengan konsep realitas sosial tersebut, informan memiliki realitas objektif dan subjektif melalui proses simultan eksternalisasi, objektifikasi, dan internalisasi. Dalam proses eksternalisasi, wartawan Kantor Berita Radio menyesuaikan diri dengan dunia sosiokultural. Kemudian, informan terpengaruh melalui interaksi sosial dalam dunia intersubjektif atau disebut proses objektifikasi. Proses eksternalisasi dan objektifikasi ini yang membuat mereka melakukan proses internalisasi, yaitu mengidentifikasi dirinya dengan lingkungannya.

Berdasarkan penjelasan di atas, tahap pertama yang dilalui informan yakni proses eksternalisasi, di mana informan mencurahkan ekspresinya ke dalam dunia, baik dalam kegiatan mental maupun fisik. Proses ini merupakan bentuk ekspresi diri untuk menguatkan eksistensi individu dalam masyarakat. Pada tahap eksternalisasi, masyarakat dilihat sebagai produk manusia (society is a human product), yang mana informan sudah memiliki pandangan subjektif sendiri mengenai realitas yang dialami.

Hasil penelitian menunjukkan, dalam kesehariannya para informan menunjukkan diri di hadapan masyarakat lewat penampilan yang sederhana - jika dibandingkan dengan pekerja kelas menengah ke atas lain yang menjadi mayoritas pekerja kantoran di ibu kota. Mereka juga menampilkan gaya hidup yang sederhana tanpa berfoya-foya. Sebagian besar informan pun menggunakan alat transportasi umum dalam kegiatannya sehari-hari, seperti kereta, bus dan ojek online. Sebagian informan sudah memiliki kediaman sendiri yang ditempati bersama keluarga, sedangkan sebagian lagi masih tinggal di rumah kontrakan dan sewa kost. Secara umum, kesan yang ditampilkan para informan kepada lingkungan sekitarnya memberikan pandangan bahwa sebagian dari mereka cukup sejahtera, sebagian lagi belum.

Kemudian tahap penting lain yang dilewati informan dalam mengonstruksi realitas atas kesejahteraan yakni melalui proses objektivasi. Objektivasi adalah proses interaksi sosial dalam dunia intersubjektif yang dilembagakan atau mengalami institusionalisasi. Dalam arti kata lain, hasil yang telah dicapai, baik mental maupun fisik dari kegiatan eksternalisasi manusia itu sendiri. Hasil tersebut berupa realitas objektif yang akan menghadapi subjek penghasil itu sendiri sebagai suatu faksitas (kefaktaan) yang telah ada, berbeda dari manusia yang menghasilkannya dan hadir dalam wujud yang nyata. Realitas objektif ini berbeda dengan kenyataan subjektif perorangan, yang mana merupakan kenyataan empiris yang bisa dialami oleh setiap manusia. Dalam tahap ini, masyarakat dilihat sebagai realitas yang objektif (society is an objective reality).

Terdapat sejumlah pandangan atau penilaian dari berbagai pihak-yang merupakan bagian dari masyarakat - terhadap kesejahteraan informan sebagai wartawan Kantor Berita Radio. Berdasarkan hasil penelitian, penilaian pertama datang dari pemimpin redaksi Kantor Berita Radio sendiri, Citra Dyah Prastuti, yang menyatakan bahwa kesejahteraan wartawan KBR secara materi dan jumlah gaji—sebagai salah satu aspek penentu kesejahteraan-jika dibandingkan dengan wartawan media massa radio lainnya sudah hampir sama bahkan cukup

http://jurnal.unpad.ac.id/kajian-jurnalisme 
lebih baik. Kendati ia mengakui bahwa perbandingannya juga jauh berbeda dengan wartawan dari media massa televisi ataupun cetak.

Berdasarkan hasil riset AJI mengenai upah layak wartawan, dapat ditarik kesimpulan bahwa wartawan KBR belum dianggap sejahtera, jika melihat dari sisi materi yakni jumlah gaji yang dibandingkan dengan media massa lainnya - tanpa mengesampikan aspek lain yang turut membentuk konstruksi realitas terhadap kesejahteraan, sisi materi pun menjadi poin penting dalam pertimbangan tersebut.

Secara keseluruhan, dalam proses objektivasi ini wartawan Kantor Berita Radio dipandang belum sejahtera. Pun hal ini juga tercermin dari semua informan yang mengaku bahwa mereka belum merasa sejahtera dari sisi materi. Kendati demikian, tiap-tiap informan memiliki ukuran-ukuran tersendiri dalam memaknai kesejahteraan itu sendiri, yang tentunya berbeda dari pandangan pada umumnya.

Proses selanjutnya yaitu internalisasi. Internalisasi merupakan penyerapan kembali realitas objektif ke dalam kesadaran manusia, sehingga individu tersebut dipengaruhi oleh struktur dunia sosial. Berbagai macam unsur dari $\mathrm{u}=$ dunia yang telah terobjektifikasi tersebut akan dipahami manusia sebagai gejala realitas di luar kesadarannya, sekaligus sebagai gejala internal bagi kesadaran. Melalui internalisasi, manusia menjadi hasil dari masyarakat (man is a social product).

Dalam proses internalisasi ini, kenyataan empiris yang dibentuk pada objektivasi diterima, diikuti, dan diyakini oleh wartawan Kantor Berita Radio sehingga menjadi seperangkat nilai, di mana informan meyakini bahwa kenyataannya dirinya sejahtera atau tidak sejahtera.

Namun berdasarkan penelitian yang dilakukan, hasil objektivasi ini tidak dianggap sepenuhnya sesuai, dan terdapat penilaian tersendiri dari masing-masing informan. Hal ini disebabkan oleh ukuran kesejahteraan yang berbeda dari tiap individu. Adapun masyarakat pada umumnya cenderung menilai dan memandang kesejahteraan dari aspek materi yang terlihat.

Informan pertama, Dimas Rizky Chrisnanda, merasa keadannya saat ini belum sejahtera, jika memang melihat dari sisi materi. Namun, kesejahteraan menurutnya tidak hanya diukur dari sisi materi saja, pun dari sisi sosial serta mental menjadi hal yang berpengaruh baginya, yang mana menurutnya ia sudah merasa sejahtera dengan keadaan sosial dan mentalnya dengan bekerja di KBR. Menurutnya, interaksi serta ikatan hubungan dengan rekan kerja menjadi aspek penting yang membuatnya merasa sejahtera.

Informan kedua, Nurika Manan menilai bahwa dari gaji yang ia dapatkan sudah mencukupi kebutuhannya, walaupun tidak serta-merta membuatnya merasa sejahtera. Kecukupan tersebut dipengaruhi oleh faktor Ika yang belum berkeluarga, meski ia sudah mampu membantu keluarganya di kampung. Kesejahteraan bagi Ika pun dapat dinilai dari aktivitasnya sehari-hari, di mana menurutnya saat ini ia memandang akan merasa lebih sejahtera jika masih bisa turun ke lapangan sebagai reporter, kendati jabatannya kini sudah menjadi editor. Selain itu, menurut Ika kesederhanaan pun menjadi aspek penting dalam hidupnya, yang berpengaruh terhadap gaya hidup, dan menjadikan keyakinannya tentang 
51 | Kajian Jurnalisme

ISSN 2549-0559 (cetak) ISSN 2549-1946 (online)

Volume 02 Nomor 01 Tahun 2018

kesejahteraan tidak melulu soal materi yang berlebihan-berbeda dengan pandangan umumnya yang didominasi oleh aspek materi.

Informan ketiga, Bambang Harisumarto meyakini bahwa ia belum sejahtera dengan apa yang didapatkan dari KBR, kendati secara sosial maupun mental masih merasa sejahtera. Satu kasus menarik dialami Bambang di mana tetangga sekitarnya menganggap profesi yang ditangung Bambang sebagai wartawan tidak bisa membuatnya sejahtera, kendati ia bisa menghidupi istri serta ketiga anaknya. Selain menjadi wartawan, Bambang pun memiliki pekerjaan lain yang tidak diketahui banyak orang. Selain itu, Bambang juga mengaku bahwa lingkungannya menganggap bahwa tingkat kesejahteraan profesi wartawan masih jauh tertinggal dibandingkan sejumlah profesi lain.

Informan keempat, Ade Irmansyah mengaku belum merasa sejahtera dari sisi materi. Ia menjelaskan bahwa kebutuhan sehari-harinya belum tercukupi dari gaji yang ia dapatkan di KBR. Ia juga menilai kesejahteraan dipengaruhi oleh kenyamanan dan keamanan bekerja, yang mana belum ia rasakan juga selama menjadi wartawan KBR. Di balik itu, Ade sudah merasa sejahtera dari sisi sosial dan mental, melihat hubungan kekerabatan yang dimiliki membuatnya senang dan mampu menjadikannya wartawan yang lebih baik.

Penjabaran di atas menggambarkan bahwa tiga proses berkesinambungan eksternalisasi, objektivasi, dan internalisasi dialami berbeda-beda oleh masing-masing informan. Tidak semua informan menerima hasil objektivasi berupa pandangan luas masyarakat sebagai kenyataan yang diyakini atau internalisasi.

Model Konstruksi Realitas Kesejahteraan Wartawan Kantor Berita Radio

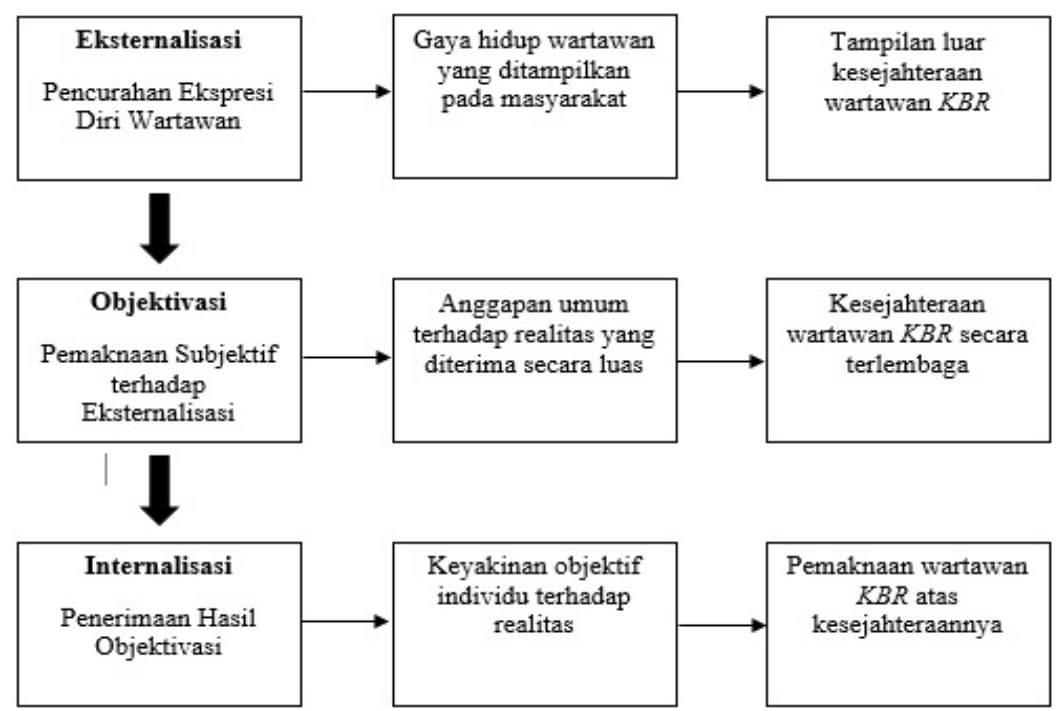

Gambar 1 Proses Konstruksi Realitas Kesejahteraan Wartawan KBR Sumber : Olahan Peneliti 
Kajian Jurnalisme

ISSN 2549-0559 (cetak) ISSN 2549-1946 (online)

Volume 02 Nomor 01 Tahun 2018

\section{Motif Informan}

Dalam memilih profesinya sebagai jurnalis, informan memiliki sebuah motif yang menjadi alasan serta garis besar dari pilihannya. Motif ini dapat dianalisis dengan teori fenomenologi sosial Alfred Schutz. Motif informan ini akan dilihat dari pengalaman hidup mereka. Dalam melihat konsep tindakan (action), Alfred Schutz (1967:14) dalam bukunya The Phenomenology of the Social World menjelaskan bahwa tindakan adalah perilaku yang diarahkan pada realisasi atas penentuan tujuan di masa depan.

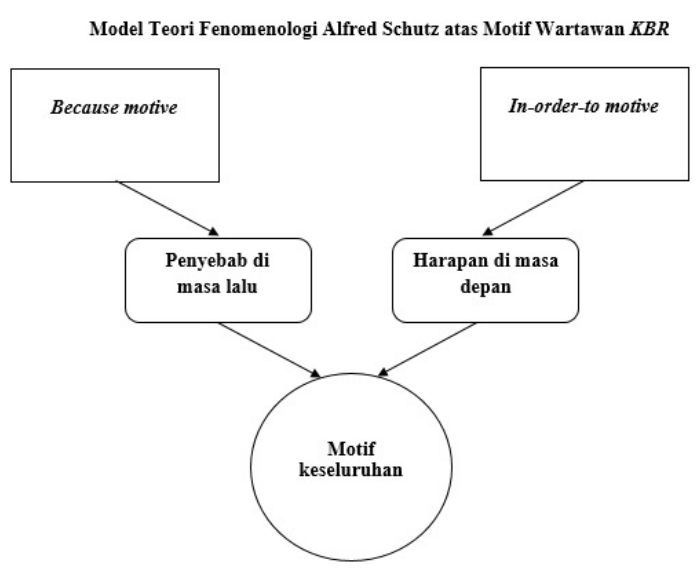

Gambar 2 Cara Kerja Teori Fenomenologi Sosial Alfred Schutz dalam Penelitian ini Sumber: Olahan Peneliti

Informan pertama, Dimas Rizky Chrisnanda menjelaskan pengalamannya dulu yang membuat ia ingin menjadi wartawan di KBR. Keinginan menjadi wartawan sudah ada sejak ia lulus kuliah. Lulusan jurusan sastra Indonesia Universitas Sanata Dharma Yogyakarta ini mengaku sebelumnya sudah mengetahui tentang KBR sebelum ia bekerja di sana, berkat kakaknya yang pernah menjadi wartawan magang di sana. Dimas sendiri meyakini bahwa dirinya sebagai lulusan non-jurnalistik mampu menjadi wartawan yang baik. Terdapat beberapa alasan yang memantapkan niat Dimas untuk menjadi jurnalis KBR, salah satunya karena independensi yang dinilainya baik. Selain itu, ia juga menyebutkan ingin memiliki profesi yang dapat membantu orang lain. Dengan menjadi wartawan, ia merasa sudah membantu publik dengan informasi-informasi yang disampaikan.

Setelah menjadi wartawan, Dimas mengaku tidak memiliki target khusus dalam karirnya ke depan. Ia mengaku hanya ingin fokus untuk bisa menjadi wartawan yang lebih baik lagi. Salah satu tujuan awal Dimas ingin menjadi wartawan yakni membuktikan dirinya sebagai lulusan non-jurnalistik pun mampu menjadi wartawan. Dimas menjelaskan bahwa ia memiliki ekspektasi terhadap perusahaan untuk ke depannya bisa mempertimbangkan kesejahteraan para wartawannya lebih baik lagi. Kendati demikian, ia mengaku tidak sepenuhnya yakin akan bertahan dalam jangka waktu panjang di KBR. Seandainya memiliki kesempatan, ia menyebutkan bahwa ingin bekerja di media cetak Kompas dengan alasan kesejahteraan yang lebih baik. Namun, selama masih bekerja di KBR, Dimas berjanji akan terus loyal pada 
53 | Kajian Jurnalisme

ISSN 2549-0559 (cetak) ISSN 2549-1946 (online)

Volume 02 Nomor 01 Tahun 2018

perusahaannya.

Informan kedua, Nurika Manan menceritakan awal mula ia memilki ketertarikan pada dunia jurnalistik karena hobinya membaca. Dengan hobinya tersebut, ia merasa bahwa wartawan merupakan profesi yang cocok bagi dirinya. Lulusan arsitektur lanskap Institut Pertanian Bogor ini sempat bekerja di perusahaan konsultan, sebelum akhirnya memutuskan untuk menjadi wartawan di KBR pada akhir tahun 2012. Ketertarikannya terhadap dunia jurnalistik pun bertambah saat ia mempelajari proses peliputan yang menurutnya menyenangkan. Ika juga mengaku sudah mengetahui beberapa hal tentang KBR sebelum ia bekerja di sana.

Dalam menjelaskan motif masa depannya, Ika mengaku tidak memiliki target tertentu. Kurun waktu lima tahun lebih yang sudah ia lewati sebagai wartawan KBR membuatnya tidak yakin akan bertahan di sana. Hal ini disebabkan oleh kejenuhan Ika dalam menjalani aktivitasnya sehari-hari sebagai wartawan KBR. Kejenuhan tersebut datang karena Ika kini telah menjabat sebagai editor, yang kegiatannya relatif lebih banyak dihabiskan di kantor dari pada di lapangan. Ika memiliki ekspektasi terhadap perusahaan untuk melakukan perubahan serta inovasi dari sisi penyajian informasi hingga program-program siarannya. Selain itu juga Ika menginginkan adanya kenaikan fasilitas bagi para wartawan KBR supaya lebih sejahtera. Seandainya Ika mempunyai pilihan, ia ingin bekerja di media daring Tirto. Adapun tujuan lain Ika di masa depan yakni lebih ingin kembali ke kampung halamannya di Bojonegoro.

Informan ketiga, Bambang Harisumarto memiliki keinginan menjadi wartawan sejak ia kecil. Keinginan tersebut tumbuh karena sosok bapaknya yang pada saat itu menjadi wartawan di media asing. Keinginannya tersebut berlanjut hingga akhirnya ia lulus dari jurusan jurnalistik Institut Ilmu Sosial dan Ilmu Politik Jakarta. Bambang mengaku bahwa sebelumnya ia sudah mengetahui tentang KBR ini. Sama dengan Dimas, alasan Bambang memilih menjadi wartawan KBR karena kredibilitasnya yang dikenal independen dan tidak ada intervensi dari pemilik media.

Adapun motif masa depan yang dimiliki Bambang yakni berhenti menjadi wartawan saat usia empat puluh tahun. Menurutnya, masa tujuh tahun yang telah ia lalui sebagai wartawan sudah membuatnya puas dari apa yang ia cita-citakan sebelumnya. Keinginan Bambang menjadi jurnalis di antaranya melakukan liputan dan siaran, dan itu sudah berhasil ia capai dalam dua tahun awal masa kerjanya di KBR. Sempat ada keinginan dari Bambang untuk pindah tempat kerja, namun hal itu tidak pernah terealisasi. Mengenai ekspektasi Bambang terhadap perusahaan, sama dengan Dimas dan Ika yang menginginkan adanya kenaikan gaji dan fasilitas untuk lebih mensejahterakan. Selain itu, Bambang juga mengharapkan perusahaan dapat memberikan apresiasi lebih kepada para wartawannya yang sudah loyal dan menghabiskan waktu lebih dari lima tahun di KBR.

Informan keempat, Ade Irmansyah menceritakan bahwa ia sudah bercita-cita menjadi wartawan sejak duduk di bangku kuliah. Pada saat mengenyam pendidikan di ilmu sejarah Universitas Padjadjaran, ia melihat kagum rekan-rekan serta seniornya yang menjadi wartawan. Walaupun memiliki keinginan yang besar untuk menjadi wartawan, Ade mengaku ia sama sekali tidak memiliki basis jurnalistik dalam dirinya. Saat menjadi wartawan KBR pada

http://jurnal.unpad.ac.id/kajian-jurnalisme 
Oktober 2012 pun ia masih dalam tahap belajar untuk menjadi jurnalis. Keinginannya menjadi wartawan pun tidak didorong dengan pengetahuannya tentang KBR, bahkan ia mengaku baru tahu tentang KBR saat ingin melamar menjadi wartawan di sana.

Bagi Ade, yang menjadi motif masa depannya yaitu ingin menguasai salah satu desk dalam redaksi, kemudian menjadi ahli dalam bidang tersebut. Namun, sejauh ini Ade mengaku belum dapat mencapai target yang ia cita-citakan itu. Sama seperti ketiga informan lainnya, Ade memiliki ekspektasi terhadap perusahaan untuk lebih mensejahterakan para wartawannya. Seperti halnya Bambang, Ade pun mengaku sudah berkali-kali ingin pindah tempat kerja dari $\mathrm{KBR}$, namun hal itu tidak terealisasi higga kini. Jika nantinya ia harus keluar dari KBR, Ade tidak ingin lagi menjadi jurnalis.

\section{Motif Karya Informan}

Bagi seorang jurnalis, pemaknaan kesejahteraan memiliki implikasi terhadap karya jurnalistiknya, termasuk dalam bentuk manifestasi kualitas dan kuantitas karyanya. Hal ini tentunya berlaku pada informan yang menjadi wartawan Kantor Berita Radio. Bagi semua informan, kesejahteraan yang dirasakan sebagai wartawan KBR ini berpengaruh terhadap kinerja serta kualitas dan kuantitas karya jurnalistik mereka.

Informan pertama, Dimas Rizky Chrisnanda mengaku bahwa kesejahteraan yang ia rasakan di KBR memiliki pengaruh terhadap kualitas karya yang dibuat. Dalam kondisi tertentu, kebutuhan hidup termasuk keluarganya menjadi prioritas. Di saat kebutuhan itu tidak tercukupi, Dimas mengaku bahwa itu akan membuat fokusnya terganggu dan pada akhirnya berdampak terhadap pekerjaannya.

Informan kedua, Nurika Manan menilai bahwa rasa sejahtera memengaruhi kinerjanya sebagai wartawan. Berbeda dengan Dimas, kesejahteraan yang dimaksud Ika bukan terhadap kecukupannya memenuhi kebutuhan sehari-hari, tetapi pada selisih gaji yang diterapkan di KBR. Menurutnya, selisih gaji antara wartawan pemula dengan wartawan yang sudah menjabat sebagai editor dengan tolak ukur masa kerja di atas lima tahun terlalu sedikit. Hal ini membuatnya merasa bahwa ia pantas untuk mendapatkan kesejahteraa lebih, jika dilihat dari jumlah gaji. Selain itu, menurutnya kegiatan sehari-hari juga memengaruhi kesejahteraannya. Jabatannya kini sebagai editor membuat Ika mengerjakan tugasnya hanya dari kantor. Hal itu membuatnya kerap merasa jenuh dengan aktivitasnya sehari-hari. Menurutnya, ia akan merasa lebih sejahtera jika ia terjun langsung ke lapangan selaku reporter.

Beda lagi dengan kasus yang dialami Bambang. Menurutnya, kesejahteraan yang ia rasakan memang berpengaruh terhadap kinerjanya, tetapi lebih pada anggapannya atas beban kerja yang tidak seimbang dengan jumlah gaji yang diterima. Hal itu terkadang membuatnya merasa terpaksa dan mau tidak mau dalam menyelesaikan tugasnya.

Hampir sama dengan Bambang, informan keempat yaitu Ade Irmansyah juga merasa bahwa kesejahteraan yang ia rasakan berpengaruh terhadap kualitas dan kuantitas pekerjaannya. Dengan jumlah gaji yang dianggap masih kurang mencukupi kebutuhan, tak jarang membuatnya merasa malas-malasan dalam menghadapi tuntutan pekerjaannya. 
55 | Kajian Jurnalisme

ISSN 2549-0559 (cetak) ISSN 2549-1946 (online)

Volume 02 Nomor 01 Tahun 2018

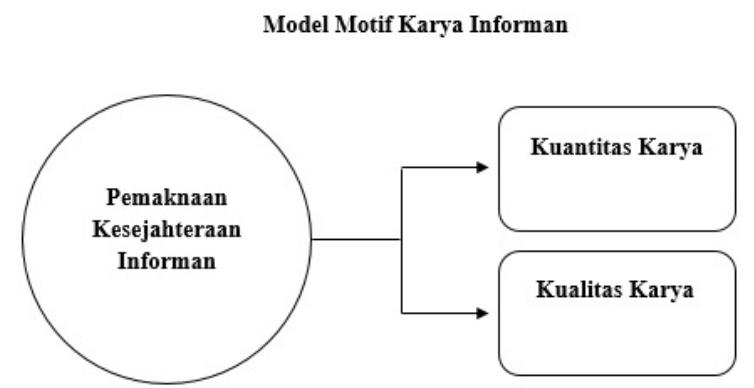

Gambar 3 Pemaknaan Kesejahteraan dan Implikasinya terhadap Kualitas Karya Sumber : Olahan Peneliti

Dari uraian implikasi di atas, semua informan mengaku adanya pengaruh kuat kesejahteraan terhadap motif karya mereka. Implikasi terhadap karya, dalam hal ini diurai atas dua hal, di antaranya kuantitas dan kualitas karya. Kuantitas adalah jumlah karya yang dihasilkan setiap harunya, sedangkan kualitas adalah mutu dari karya yang dihasilkan.

Dari keempat informan yang memiliki jabatan berbeda, secara garis besar kuantitas karya yang mereka produksi sudah cukup baik dan memenuhi kebutuhan serta tuntutan redaksi. Hal ini dijabarkan oleh masing-masing informan, mulai dari Dimas selaku supervisor reporter atau koordinator liputan yang dalam sehari dapat menaikkan sekaligus mengedit 25 berita, dengan rincian berita online maupun radio. Ika yang menjabat sebagai editor, dalam sehari bisa menaikkan dan mengedit sepuluh hingga dua belas berita. Namun, ia tak hanya mengedit berita, tetapi juga mengurus program siaran, manajemen isu, atau bahkan sesekali liputan dan wawancara via telepon. Bambang dan Ade yang jabatannya sebagai reporter dalam sehari dapat menulis tiga sampai lima berita, tergantung isu dan tempat liputan. Pengecualian pada Bambang yang tak jarang dijajarkan sebagai editor, ia juga mengurus program siaran.

Implikasi kesejahteraan pun mengikat pada kualitas karya jurnalistik para informan. Jika dilihat dari kualitas karya, Dimas dan Bambang bisa dibilang lebih baik dari Ika dan Ade. Hal ini, salah satunya, bisa diukur dari penghargaan karya jurnalistik yang pernah diraih. Dimas menceritakan bahwa dirinya pernah menjadi finalis liputan isu anak dan isu pangan yang pernah diselenggarakan oleh UNESCO dan AJI, serta FAO. Sedangkan Bambang pernah memenangkan penghargaan dari WALHI atas tulisannya bertemakan pencemaran lingkungan pada tahun 2013.

Ika dan Ade yang masing-masing menjabat sebagai editor dan reporter mengaku belum pernah memenangkan penghargaan apapun atas karya mereka. Tanpa bermaksud merendahkan diri, mereka pun mengaku bahwa kualitas karya ataupun secara keseluruhan sebagai wartawan masih biasa-biasa saja. Ika bahkan mengaku bahwa ia tidak pernah menyebutkan dirinya sebagai wartawan kepada orang lain, kecuali saat bertugas dan harus berhadapan dengan narasumber. Hal tersebut dikatakan oleh Ika karena ia merasa tanggung jawab seorang wartawan atas kebenaran yang disampaikan pada publik menjadi beban berat baginya. 
Sedangkan Ade mengakui bahwa ia masih perlu banyak belajar untuk memenuhi kualitas wartawan yang baik. Ade bahkan menyebutkan bahwa ia sering malas-malasan akibat kesejahteraan yang ia dapatkan di KBR tidak membuatnya bahagia.

\section{Kesejahteraan Informan}

Kesejahteraan atau rasa sejahtera yang dimaknai oleh para informan terbagi dalam tiga aspek; yakni kesejahteraan dari sisi materi, kesejahteraan dari sisi sosial, dan kesejahteraan dari sisi mental/psikologis para informan. Ketiga aspek inilah yang nantinya membuat informan dapat menilai apakah mereka sejahtera atau tidak.

Ketiga aspek kesejahteraan tersebut dapat dikelompokkan berdasarkan uraian dan pengertian kesejahteraan itu sendiri. Mulai dari Undang-undang No. 11 tahun 2009 tentang Kesejahteraan Sosial yang mendefinisikan kesejahteraan sebagai kondisi terpenuhinya kebutuhan material, spiritual, dan sosial warga negara agar dapat hidup layak dan mampu mengembangkan diri, sehingga dapat melaksanakan fungsi sosialnya. Selain itu, dalam Undang-undang No. 13 tahun 2003 tentang Ketenagakerjaan menyebutkan bahwa kesejahteraan pekerja/buruh adalah suatu pemenuhan kebutuhan dan/atau keperluan yang bersifat jasmaniah dan rohaniah, baik di dalam mauoun di luar hubungan kerja, yang secara langsung atau tidak langsung dapat mempertinggi produktivitas kerja dalam lingkungan kerja yang aman dan sehat.

Sedangkan, dalam Undang-undang No. 40 tahun 1999 tentang Pers sendiri menyatakan bahwa perusahaan pers memberikan kesejahteraan kepada wartawan dan karyawan pers dalam bentuk kepemilikan saham dan atau pembagian laba bersih serta bentuk kesejahteraan lainnya. Yang dimaksud dengan bentuk kesejahteraan lainnya adalah peningkatan gaji, bonus, pemberian asuransi dan lain-lain. Pemberian kesejahteraan tersebut dilaksanakan berdasarkan kesepakatan antara manajemen perusahaan dengan wartawan dan karyawan pers.

Masuk ke dalam pembahasan aspek-aspek kesejahteraan informan yang sudah diuraikan sebelumnya. Kelompok kesejahteraan yang pertama yakni kesejahteraan dari sisi materi. Berdasarkan hasil penelitian, pada umumnya masing-masing informan masih belum merasa sejahtera dari sisi materi. Ada sejumlah faktor yang mempengaruhi penilaian informan terhadap kesejahteraan sisi materi mereka. Alasan yang kerap muncul dalam penelitian ini yakni faktor kebutuhan keluarga, yang mana sebagian besar informan sudah berkeluarga dan tentunya mempengaruhi kebutuhan mereka. Hal ini juga dijelaskan oleh ketua AJI Jakarta yang menjelaskan bahwa wartawan yang sudah berkeluarga memiliki kebutuhan lebih, seperti tempat tinggal dan tabungan.

Mengacu pada aturan perundang-undangan yang ada, seseorang dapat dikatakan sejahtera, setidaknya harus dapat hidup memenuhi standar Kebutuhan Hidup Layak berdasarkan keputusan Menteri Tenaga Kerja No. 13 tahun 2012. Standar KHL itu terdiri atas biaya untuk makanan dan minuman, sandang, perumahan, pendidikan, kesehatan, transportasi, serta rekreasi dan tabungan.

Senada dengan peraturan di atas, AJI Jakarta merilis survei Kebutuhan Hidup Layak Jurnalis Pemula di Jakarta tahun 2018 yang merincikan kebutuhan tersebut dan dialokasikan 
57 | Kajian Jurnalisme

ISSN 2549-0559 (cetak) ISSN 2549-1946 (online)

Volume 02 Nomor 01 Tahun 2018

ke dalam jumlah upah layak wartawan.

Survei AJI Jakarta mengenai kebutuhan hidup layak jurnalis pemula di Jakarta tahun 2018 ini mencatat bahwa jumlah gaji yang layak diberikan pada wartawan ada pada angka Rp7.963.949,-. Sedangkan dari hasil penelitian, jumlah gaji informan yang sudah melewati masa kerja di atas lima tahun ada pada kisaran Rp5.000.000 - Rp5.700.000,-. Hal ini tentunya membuat para informan merasa belum sejahtera dari sisi materi.

Selain memberikan kesejahteraan material, perusahaan pers juga wajib memberikan kesejahteraan sosial bagi para karyawannya. Kesejahteraan dari sisi sosial berupa ketentraman dalam hubungan sosial dalam interaksi bersama, baik di lingkungan keluarga, lingkungan kerja, tempat tinggal, maupun lingkungan masyarakat luas. Kesejahteraan sosial didapat apabila seseorang merasakan kenyamanan dan ketentraman dalam hubungan sosialnya.

Hasil penelitian menunjukkan para informan sudah merasa cukup sejahtera secara sosial. Kesejahteraan sosial ini dirasakan dari interaksi sosial dan iklim kerja yang dialami oleh para informan. Mereka mengaku bahwa hubungan kekerabatan yang dimiliki oleh tiap-tiap wartawan maupun karyawan di KBR cukup erat dan terbuka. Dengan kekerabatan yang baik, membuat para informan merasa terbantu dalam menyelesaikan tuntutan-tuntutan kerja. Bahkan, beberapa informan menganggap bahwa rekan kerja di KBR sudah menjadi bagian dari keluarga besar karena kedekatan yang begitu erat.

Hal ini juga diakui oleh pemimpin redaksi Kantor Berita Radio, Citra Dyah Prastuti yang menyebutkan hubungan kekerabatan di KBR sudah sangat dekat dan terasa seperti keluarga. Alur komunikasi yang terjalin pun terbuka, baik antara sesama wartawan maupun antara atasan dengan bawahan.

Adapun kesejahteraan dari sisi mental yang dapat diukur dari kebahagiaan, atau dalam istilah ilmiahnya disebut sebagai kesejahteraan subjektif. Kesejahteraan subjektif mencerminkan evaluasi individu terhadap kehidupan mereka, termasuk di dalamnya kebahagiaan, emosi, dan kepuasan hidup. Semakin banyak emosi yang menyenangkan dan sedikit emosi yang tidak mengenakkan maka semakin tinggi kesejahteraan subjektif individu (Diponegoro, 2006: 137).

Bagi para informan, kesejahteraan sosial memiliki pengaruh penting terhadap kesejahteraan mental/psikologis mereka. Sebagian besar informan mengaku merasa bahagiayang merupakan aspek penting dari kesejahteraan mental - dengan hubungan kekerabatan yang mereka miliki selama bekerja di KBR. Selain itu, dalam melaksanakan tugasnya seharihari, para informan mengaku sudah merasa cukup bahagia.

Ada beberapa hal berbeda yang mempengaruhi kesejahteraan mental bagi para informan. Sebetulnya, kesejhateraan mental ini tidak setiap saat dirasakan oleh beberapa informan, seperti Ika dan Bambang. Dalam kasusnya, Ika merasa sering jenuh dengan pekerjaan dan aktivitasnya yang ia jalani sehari-hari. Menurutnya, kejenuhan tersebut timbul karena aktivitas sehari-hari yang sama, tidak ada perubahan selama bertahun-tahun ia menjadi jurnalis di KBR. Sedangkan, bagi Bambang, aspek yang dipertimbangkan atas ukuran kebahagiannya yakni tuntutan kerja yang dirasa tidak seimbang dengan jumlah gaji yang ia dapatkan. Hal ini mempengaruhi pandangannya terhadap kesejahteraan mental yang ia rasakan. 
Di balik itu semua, pemaknaan informan terhadap kesejahteraan sosial dan mental yang mereka rasakan tak lepas dari budaya kerja (kerja, pekerjaan, dan interaksi kerja), yang terbentuk di Kantor Berita Radio. Dalam hal ini, pekerjaan yang dibebankan untuk mereka, tuntutan perusahaan atas kinerja mereka, serta interaksi sosial yang merka alami sangat menentukan pemaknaan mereka terhadap kesejahteraan secara sosial dan mental/psikologis.

\section{Simpulan}

1. Dalam memaknai kesejahteraannya, setiap informan memiliki proses pemaknaan yang berbeda-beda. Hasil penelitian membuktikan bahwa kesejahteraan tak hanya diukur dari sisi materi. Secara umum, ada tiga aspek yang digunakan, di antaranya: kesejahteraan material yang berupa segala manfaat ekonomi; kesejahteraan sosial yang berupa interaksi dan hubungan kekerabatan; serta kesejahteraan mental atau psikologis. Meskipun menggunakan tiga ukuran yang sama, nyatanya masing-masing informan memaknai berbeda sesuai dengan pengalaman, nilai, dan pengetahuan yang dimilikinya. Konstruksi sosial yang dialami masing-masing informan juga berpengaruh terhadap pemaknaan mereka terhadap kesejahteraan, yang mana secara keseluruhan informan merasa tampilan luar kesejahteraan wartawan KBR tidak terlalu dipengaruhi oleh pendapat serta pengetahuan umum atas gaya hidup wartawan yang bagaimana seharusnya (Eksternalisasi). Kemudian, kesejahteraan yang dirasakan oleh tiap-tiap informan secara umum diakui sama dengan pendapat umum lingkungan sekitar mereka yang menyebut bahwa selaku wartawan KBR masih belum sejahtera (Objektivasi). Dari pandangan tersebut, secara umum informan meyakini bahwa kesejahteraan yang mereka rasakan masih kurang (Internalisasi).

2. Wartawan Kantor Berita Radio memiliki motif-motif tersendiri dalam memilih profesi sebagai jurnalis yang dapat ditelisik dengan teori fenomenologi sosial. Motif tersebut terbagi dalam dua hal yakni motif masa lalu (because-motive) dan motif masa depan (in-order-to-motive) yang sangat dipengaruhi pengalaman dan pengetahuan masingmasing informan. Motif masa lalu informan pada umumnya didorong atas keinginan dan cita-cita menjadi wartawan, yang kemudian memilih Kantor Berita Radio sebagai tempat mereka bernaung dengan sejumlah alasan yang dimiliki tiap-tiap informan, yang dominannya disebutkan karena independensi redaksi, dan tidak adanya intervensi dari pihak pemilik perusahaan atau manapun. Ada pula informan yang memilih Kantor Berita Radio karena hanya ada ketersediaan lowongan kerja di tempat itu, tanpa pertimbangan alasan khusus tertentu. Cita-cita menjadi wartawan dari para informan pun berbeda-beda, ada yang menjadikan ini sebagai pembuktian diri bahwa informan mampu menjadi wartawan, ada yang memang memiliki hobi membaca hingga akhirnya menjadi keinginan untuk berprofesi sebagai jurnalis, ada pula yang memilih profesi jurnalis karena kekaguman atas pengalaman yang sudah dilalui sebelumnya oleh keluarga atau kerabat. Adapun motif masa mendatang yang dimiliki para informan di 
59 | Kajian Jurnalisme ISSN 2549-0559 (cetak) ISSN 2549-1946 (online)

Volume 02 Nomor 01 Tahun 2018

antaranya untuk terus menjadi wartawan di KBR, ada pula yang ingin pindah tempat kerja ke media yang menyediakan kesejahteraan lebih baik, pun ada yang tidak ingin menjadi wartawan lagi setelah keluar dari KBR.

3. Semua informan menilai bahwa kesejahteraan yang mereka rasakan memiliki implikasi terhadap karya jurnalistik mereka, terutama dalam hal kualitas dan kuantitas. Rata-rata, implikasi pengaruh kesejahteraan terhadap kuantitas dan kualitas karya bagi tiap informan berhubungan dengan kurangnya kesejahteraan materi yang didapat sehingga membuat informan menjadi kurang termotivasi. Namun, hal itu dibantu dengan kesejahteraan sosial dan kesejahteraan mental yang dirasa cukup sehingga membangkitkan gairah para informan dalam memproduksi karya sebaik mungkin. Hal ini menjadi penting karena kuantitas dan kualitas karya jurnalistik yang dihasilkan para informan merupakan produk media yang menjadi konsumsi khalayak luas.

\section{Daftar Pustaka}

Berger, PL, \&. Luckman, T. (2013). Tafsir Sosial Atas Kenyataan: Risalah tentang Sosiologi Pengetahuan (Terj). Jakarta: LP3ES.

Bintarto. (1989). Interaksi Desa Kota dan Permasalahannya. Jakarta: Ghalia Indonesia.

Bungin, B. (2007). Metode Penelitian Kualitatif. Jakarta: PT RajaGrafindo Persada

Bungin, B. (2008). Analisis Data Penelitian Kualitatif. Jakarta: PT RajaGrafindo Persada

Creswell, JW. (2015). Penelitian Kualitatif dan Desain Riset, Edisi ke-III. Yogyakarta: Pustaka Pelajar.

Endraswara, S. (2006). Metode, Teori, Teknik Penelitian Kebudayaan. Yogyakarta: Pustaka Widyatama.

Hae, NZ., dkk. (2000). Sepuluh Pelajaran untuk Wartawan. Jakarta: LSPP.

Harahap, N. (2014). Bisnis Media vs Kemerdekaan Pers. Jakarta: PT Semesta Rakyat Merdeka.

Henshall, P. \&. Ingram, D. (2000). Menjadi Jurnalis. Yogyakarta: LKIS.

Kovach, B. \&. Rosenstiel, T. (2001). Sembilan Elemen Jurnalisme (Terj). Jakarta: Pantau.

Kusumaningrat, H. \&. Kusumaningrat, P. (2009). Jurnalistik: Teori \& Praktik. Bandung: PT Remaja Rosdakarya.

Kuswarno, E. (2009). Metodologi Penelitian Komunikasi Fenomenologi. Bandung: Widya Padjadjaran.

Lexy, JM. (2011). Metodologi Penelitian Kualitatif. Bandung: PT Remaja Rosdakarya.

Santana, S. (2005). Jurnalisme Kontemporer. Jakarta: Yayasan Obor Indonesia.

Schutz, A. (1967). The Phenomenology of the Social World. Illinois: Northwester University Press.

Sutopo, HB. (2006). Metode Penelitian Kualitatif. Surakarta: UNS Press.

Sutrisno, M. \& Putranto, H. (2005). Teori-Teori Kebudayaan. Yogyakarta: Kanisius.

Sugiyono. (2011). Metode Penelitian Pendidikan (Pendekatan Kuantitatif, Kualitatif, dan R\&D). Bandung: Alfabeta. 
Kajian Jurnalisme

ISSN 2549-0559 (cetak) ISSN 2549-1946 (online)

Volume 02 Nomor 01 Tahun 2018

Widodo. (1997). Teknik Wartawan Menulis Berita di Surat Kabar dan Majalah. Surabaya: Indah Surabaya.

Paper dan Jurnal

Aliansi Jurnalis Independen. 2012. "Konvergensi Media dan Kesejahteraan Jurnalis: Studi atas Perubahan Pekerjaan dan Kesejahteraan Jurnalis di Group Kompas Gramedia, Media Nusantara Citra, Tempo Inti Media, dan Visi Media Asia."

Aliansi Jurnalis Independen. 2014. "Pedoman Perilaku Jurnalis."

Aliansi Jurnalis Independen. 2018. "Upah Layak Jurnalis Jakarta 2018."

Manan, Abdul. 2011. "Upah Layak Jurnalis: Survey Upah Layak AJI di 16 Kota di Indonesia”. Jakarta: Aliansi Jurnalis Independen.

Undang-undang Nomor 40 Tahun 1999 tentang Pers, Undang-undang Nomor 13 Tahun 2003 tentang Ketenagakerjaan, Undang-undang Nomor 11 tahun 2009 tentang Kesejahteraan Sosial. 